\title{
Plastificação do poli(3-hidroxibutirato-co-3-hidroxivalerato) com poliéster alifático derivado de ácido lático
}

\section{Jacqueline Leme Barbosa*, Giovanni Bortoloni Perin, Maria Isabel Felisberti.}

\section{Resumo}

No presente trabalho, foram desenvolvidas formulações de poli(3-hidroxibutirato-co-3-hidroxivalerato) (PHBV) com diferentes teores (9, 17 e 23\%) de um plastificante oligomérico derivado de ácido lático, ácido adípico e 1,2-propanodiol, empregando-se a técnica de processamento por extrusão. O PHBV e o plastificante foram caracterizados estruturalmente, enquanto as formulações e seus componentes foram caracterizados com relação às propriedades térmicas e mecânicas. As formulações apresentaram um decréscimo nas temperaturas de transição vítrea e de fusão, no grau de cristalinidade e no módulo elástico, indicando que o plastificante é eficiente na modificação das propriedades do PHBV.

\section{Palavras-chave: \\ Biopolímeros, extrusão, caracterização.}

\section{Introdução}

O poli(3-hidroxibutirato) (PHB) é um biopolímero sintetizado por fermentação bacteriana. Apesar de seu potencial de aplicações por ser biodegradável, há fatores que limitam seu uso em substituição a termoplásticos derivados do petróleo. Dentre estes, destaca-se o contínuo aumento do grau de cristalinidade do PHB com o tempo, fenômeno conhecido como envelhecimento físico, que leva ao enrijecimento do material. Além disso, a faixa de temperatura de processamento deste polímero é estreita, uma vez que sua degradação térmica ocorre em temperaturas próximas a sua temperatura de fusão [1]. Uma das alternativas para tornar o PHB mais flexível e moldável é a copolimerização do 3-hidroxivalerato, formando o copolímero poli(3-hidroxibutirato-co-3hidroxivalerato) - PHBV. Entretanto, esta estratégia não elimina completamente as características mencionadas acima. Outra estratégia para modificar as propriedades do PHB é o uso de plastificantes. Estes são aditivos miscíveis com o polímero que reduzem as temperaturas de transição vítrea $(\mathrm{Tg})$, de fusão $(\mathrm{Tm})$ e o grau de cristalinidade $(X)$, como consequência do aumento do volume livre do polímero, minimizando os efeitos de envelhecimento físico e da degradação térmica durante o processamento [2]. No presente trabalho, foram desenvolvidas formulações de PHBV com diferentes teores de um plastificante baseado em ácido lático, ácido adípico e 1,2-propanodiol (PLAP). Estas formulações foram avaliadas de acordo com as propriedades térmicas e mecânicas.

\section{Resultados e Discussão}

O plastificante PLAP é constituído por ácido adípico, 1,2propanodiol e ácido lático a razão molar de 4:4:2, respectivamente, é amorfo com $\mathrm{T}_{\mathrm{g}}=-31^{\circ} \mathrm{C}$, massa molar numérica $\left(\mathrm{Mn}_{\mathrm{n}}\right)$ de 2,6 kDa e polidispersidade $(\bigoplus)$ de 2,5. $\mathrm{O}$ PHBV possui teor de valerato de $4 \mathrm{~mol} \%, \mathrm{Mn}_{\mathrm{n}}=90 \mathrm{kDa}$ e $\boxminus=2,8$. As imagens dos corpos de prova preparados por moldagem por injeção para ensaios mecânicos de tração (ASTM D638-14) e de resistência ao impacto (ASTM D256-10) das formulações de PHBV e PLAP são apresentadas na Figura 1. As análises termogravimétricas revelam que as formulações são termicamente estáveis até $200^{\circ} \mathrm{C}$. Os resultados de calorimetria diferencial exploratória e de ensaios mecânicos de tração mostram que as temperaturas de transição vítrea, de fusão, o grau de cristalinidade e o módulo elástico diminuem gradativamente com 0 aumento do teor de plastificante na formulação, Figuras $2 \mathrm{~A}, 2 \mathrm{~B}$ e $2 \mathrm{C}$. Estes resultados indicam a miscibilidade entre PHBV e o PLAP e a eficiência do PLAP como plastificante, o qual é capaz de minimizar os efeitos do envelhecimento físico e a degradação térmica durante o processamento.

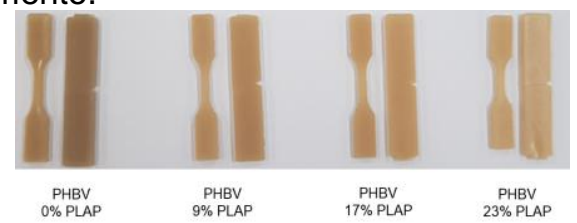

Figura 1. Corpos de prova para ensaios mecânicos de PHBV e formulações PHBV/PLAP.
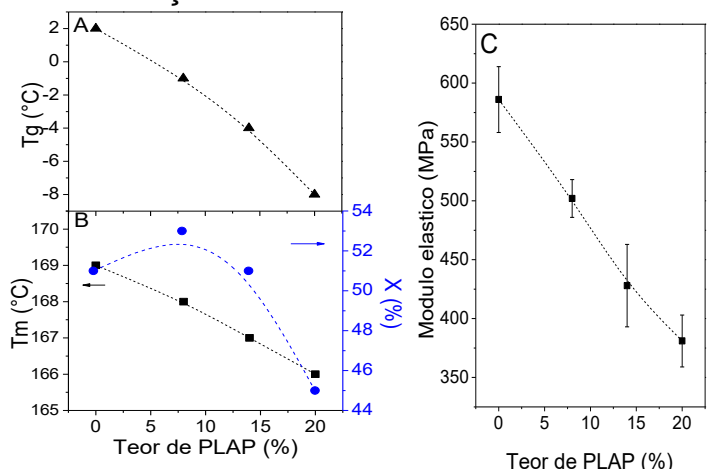

Figura 2. Dependência da $(A)$ temperatura de transição vítrea $(\mathbf{A}),(B)$ de fusão $(\mathbf{\square})$, do grau de cristalinidade $(\bullet)$ e (C) do módulo de elasticidade com o teor do PLAP.

\section{Conclusões}

A adição do plastificante PLAP modificou as propriedades térmicas e mecânicas do PHBV, diminuindo as temperaturas de transição vítrea e de fusão, o grau de cristalinidade e o módulo elástico do PHBV. Portanto, este plastificante é um aditivo adequado para modular as propriedades do PHBV e torná-lo mais atrativo na substituição de termoplásticos derivados do petróleo.

\section{Agradecimentos}

FAPESP (Processo 2018/19091-0)

${ }^{1}$ Choi, J. Y.; Lee, J. K.; You, Y. e Park, W. H. F. Polym. 2003, 4, 195.

${ }^{2}$ Wang, L.; Zhu, W.; Wang, X.; Chen, X.; Chen, G. e Xu, K. J. Appl. Polym. Sci. 2008, 107, 166 . 